\title{
Mg/Al DOUBLE LAYER HYDROXIDES: INTERCALATION WITH $\mathrm{H}_{3}\left[\alpha-\mathrm{PW}_{12} \mathrm{O}_{40}\right] \cdot \mathrm{nH}_{2} \mathrm{O}$
}

\author{
Yulizah Hanifah, ${ }^{1 *}$ and Neza Rahayu Palapa ${ }^{1}$ \\ ${ }^{1}$ Department of Chemistry, Faculty of Mathematic and Natural Sciences, Sriwijaya University \\ ${ }^{*}$ Corresponding Author e-mail :yulizahanifab@gmail.com
}

\begin{abstract}
It has been done the intercalation of polyoxometalate $\mathrm{H}_{3}\left[\alpha-\mathrm{PW}_{12} \mathrm{O} 40\right] \cdot \mathrm{nH}_{2} \mathrm{O}$ on $\mathrm{Mg}$ - $\mathrm{Al}$ double layer hydroxide by comparison weight ratio of double layer hydroxides : polyoxometalate $\mathrm{H}_{3}\left[\alpha-\mathrm{PW}_{12} \mathrm{O}_{40}\right] \cdot n \mathrm{H}_{2} \mathrm{O}$, i.e: 1:1, 1:2, $1: 3$ and 1: 4. The product of intercalated double layer hydroxide was characterized using FT-IR spectrophotometer, XRD, and TG-DTA analysis. The spectrophotometer results of FT-IR shown the process of intercalation was not optimum for every weight ratio. Characterization using XRD showed the process of intercalation was optimum at a ratio 2:1 that indicated at the area of $11,12^{\circ}, 22,85^{\circ}$ and $34,5^{\circ}$ as double layer hydroxide and at the area of $60-63^{\circ}$ showed the double layer hydroxide has intercalated with polyoxometalate. The characterization results using TGDTA analysis at the comparison 2:1 showed loss of $\mathrm{OH}$ in the layer at 170 to $220^{\circ} \mathrm{C}$ and for the decomposition of polyoxometalate $\mathrm{H}_{3}\left[\alpha-\mathrm{PW}_{12} \mathrm{O}_{40}\right] \cdot \mathrm{nH}_{2} \mathrm{O}$ at 300 to $400^{\circ} \mathrm{C}$.
\end{abstract}

Keywords: Double Layer Hydroxide, Intercalation, Polyoxometalate $\mathrm{H}_{3}\left[\alpha-\mathrm{PW}_{12} \mathrm{O}_{40}\right] \cdot n \mathrm{H}_{2} \mathrm{O}$

\section{INTRODUCTION}

Layered materials or clay of inorganic minerals are found in nature and can also be synthesized in the laboratory (Abderrazek et al, 2016). Layered material is used as a catalyst, adsorbent, sensor, membrane or ion exchange. As adsorbent, a layered material used for aditive adsorption on vegetable oil (Franchi et al, 1991) as well as its application for the control of contamination of metal ions or organic compounds in the environment.

The advantages of this double layer hydroxide have a great anion exchange properties and can be exchanged for various other anions (Beaudot et al, 2004). The general formula for double layer hydroxide is $\left[\mathrm{M}_{2+(1-\mathrm{x})} \mathrm{M}_{3+\mathrm{x}}(\mathrm{OH})_{2}\right](\mathrm{An}-) \mathrm{x} / \mathrm{n} \bullet \mathrm{nH} 2 \mathrm{O}$ which in that positive charges are balanced by the interlayer anions such as $\mathrm{Cl}^{-}, \mathrm{NO}_{3}{ }^{-}$and $\mathrm{CO}_{3}$ (Guo et al, 2014). However, The use of these layered materials still has small surface area constraints and narrow layer spacing due to the small exchange ions which are generally alkali and alkaline earth metal ions (Goodarzi et al, 2016). Double layer hydroxide still needs to be modified to increase its surface area and majority modifications made to this research are through intercalation of layered materials with atoms, molecules and complex compounds using ion exchange methods.

The purpose of this intercalation process is expected to produce double layer hydroxide intercalated macro anion that automatically increasing interlayer so it can be used as adsorbent or catalyst. The macro anion is used Polyoxometalate Keggin type $\mathrm{H}_{3}\left[\alpha-\mathrm{PW}_{12} \mathrm{O}_{40}\right] \cdot n \mathrm{H}_{2} \mathrm{O}$. The intercalated macro anion of double layer hydroxide causes the loss of the $\mathrm{OH}^{-}$anion that located on the layer so it is expected to increase the distance between layers of the double layer hydroxide.

\section{Article History}

Submitted: 2 June 2016

Accepted: 5 August 2016

DOI: 10.26554/sti.2016.1.1.16-19
In this research, synthesis and characterization of double layer hydroxide, polyoxometalate $\mathrm{H}_{3}\left[\alpha-\mathrm{PW}_{12} \mathrm{O}_{40}\right] \cdot n \mathrm{H}_{2} \mathrm{O}$ and double layer hydroxide intercalated polyoxometalate $\mathrm{H}_{3}[\alpha-$ $\left.\mathrm{PW}_{12} \mathrm{O}_{40}\right] \cdot n \mathrm{H}_{2} \mathrm{O}$ has been done. Characterization has been conducted using Fourier Transform Infra Red (FT-IR), X-Ray Diffractometer (XRD) and Thermo Gravimetric-Differential Thermal Analysis (TG-DTA).

\section{EXPERIMENTAL SECTION}

\section{Material and Methods}

Double layer hydroxide intercalated with $\mathrm{H}_{3}[\alpha-$ $\left.\mathrm{PW}_{12} \mathrm{O}_{40}\right] \cdot n \mathrm{H}_{2} \mathrm{O}$ was performed by ion exchanged method. Characterization of the synthesized compounds was performed by different techniques such as FTIR, X-Ray Diffractometer (XRD). XRD was performed using Shimadzu Lab X-type 6000 to determine the surface area before and after intercalated. The TG-DTA analysis of double layer hydroxide intercalated Polyoxometalate $\mathrm{H}_{3}\left[\alpha-\mathrm{PW}_{12} \mathrm{O}_{40}\right] \cdot n \mathrm{H}_{2} \mathrm{O}$ was evaluated using Shimadzu TG / DTA $60 \mathrm{~A}$ analyzer from $20^{\circ} \mathrm{C}$ to $800^{\circ} \mathrm{C}$.

\section{Preparation of $\mathrm{Mg}-\mathrm{Al} \mathrm{LDH}$ and $\mathrm{H}_{3}\left[\alpha-\mathrm{PW}_{12} \mathrm{O}_{40}\right] \cdot \mathrm{nH}_{2} \mathrm{O}$ composite}

\section{Preparation of $\mathrm{Mg}-\mathrm{Al} \mathrm{LDH}$}

$\mathrm{Mg}-\mathrm{Al} \mathrm{LDH}$ was synthesized by mixing $64.01 \mathrm{~g}$ of $\mathrm{Mg}\left(\mathrm{NO}_{3}\right)_{2} \cdot 6 \mathrm{H}_{2} \mathrm{O}(2 \mathrm{~mol})$ and $46.64 \mathrm{~g}$ of $\mathrm{Al}\left(\mathrm{NO}_{3}\right)_{3} .9 \mathrm{H}_{2} \mathrm{O}(1$ mol) were dissolved in $150 \mathrm{~mL}$ of aquadest (solution A). $10.00 \mathrm{~g}$ of $\mathrm{NaOH}$ and $26.62 \mathrm{~g}$ of $\mathrm{NaCO}_{3}$ was poured into $150 \mathrm{~mL}$ aquadest (solution B). Solution A is added to solution B and stirred gradually with the addition of aquadest of $100 \mathrm{~mL}$ and a $\mathrm{pH}$ adjusted from 9 to 10 to form sediment. The sediment is dried into oven at $80^{\circ} \mathrm{C}$ and ready to be characterized using FTIR spectroscopy and XRD analysis.

\section{Preparation of Polyoxometalate $\mathrm{H}_{3}\left[\alpha-\mathrm{PW} W_{12} \mathrm{O}_{40}\right] \cdot \mathrm{nH}_{2} \mathrm{O}$ composites \\ $125 \mathrm{~g}$ of sodium tungstate and $20 \mathrm{~g}$ of sodium phosphate were mixed with $187.5 \mathrm{ml}$ of boiling water in $500 \mathrm{~mL}$ of a glass}


beaker. $100 \mathrm{ml}$ of hydrochloric acid is added dropwise to the mixture and stirred using a magnetic stirrer. The stirring process is continuous until all the solid dissolve. The phosphotungstate acid will begin to separate when half of the hydrochloric acid is added then the resulting solution becomes clear and cooled. A $75 \mathrm{~mL}$ of diethyl ether cold solution was added and then extracted. After extraction process obtained three layers, the solution separated and taken from the bottom layer. The lowest layer was evaporate using a rotary evaporator to obtain white solid that is $\mathrm{H}_{3}\left[\alpha-\mathrm{PW}_{12} \mathrm{O}_{40}\right] \cdot n \mathrm{H}_{2} \mathrm{O}$. Characterization of $\mathrm{H}_{3}[\alpha-$ $\left.\mathrm{PW}_{12} \mathrm{O}_{40}\right] \cdot n \mathrm{H}_{2} \mathrm{O}$ was performed using FT-IR spectrophotometer and XRD analysis.

\section{Intercalation of LDH-POM}

Intercalation process of double layer hydroxides by polyoxometalate $\mathrm{H}_{3}\left[\alpha-\mathrm{PW}_{12} \mathrm{O}_{40}\right] \cdot n \mathrm{H}_{2} \mathrm{O}$ by ion exchange method was carried out by preparing $1 \mathrm{~g}$ of $\mathrm{H}_{3}\left[\alpha-\mathrm{PW}_{12} \mathrm{O}_{40}\right] \cdot n \mathrm{H}_{2} \mathrm{O}$ (solution A) mixed with $50 \mathrm{~mL}$ of distilled water, and $2 \mathrm{~g}$ of double layer hydroxide was added with $25 \mathrm{~mL} \mathrm{NaOH} 1 \mathrm{M}$ (solution B). Solution A and solution B are then mixed rapidly under conditions given $\mathrm{N}_{2}$ gas for 24 hours. Then the suspension is cooled and the product is washed with water and dried at room temperature. Structural analysis, the thermal stability of the inserted product is carried out using XRD, FTIR and TG-DTA.

\section{RESULTS AND DISCUSSION}

\section{Characterization of LDH-POM}

$\mathrm{Mg}-\mathrm{Al} \mathrm{LDH}$ and LDH-POM using comparison 1:1, 1:2, 1:3 and 2:1. The characterization of the FT-IR spectra aims to identify the functional groups formed as shown in Figure1.

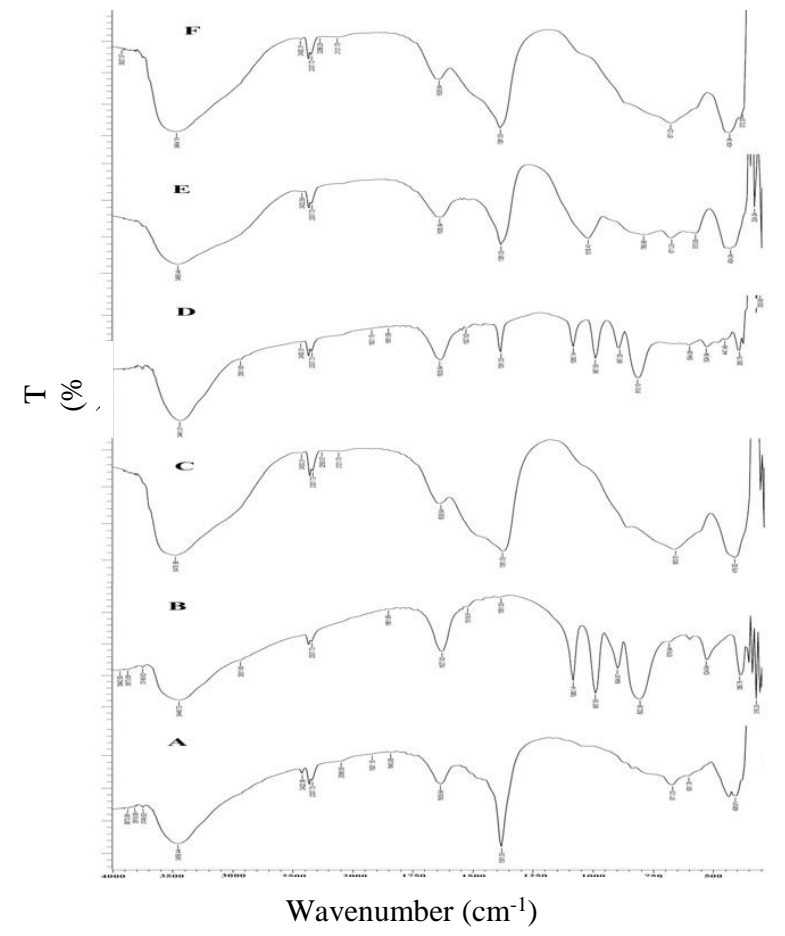

Figure 1. FT-IR spectra of (A) double layer hydroxide (B) Polyoxometalate $\mathrm{H}_{3}\left[\alpha-\mathrm{PW}_{12} \mathrm{O}_{40}\right] \cdot n \mathrm{H}_{2} \mathrm{O}(\mathrm{C})$ Intercalation LDHPOM with a rasio 1:1 (D) 1:2 (E) 1:3 (F) 2:1.
The FT-IR spectrum of LDH is presented in Figure 1. At 671 and $1381 \mathrm{~cm}^{-1}$ which are indicated nitrate bend and the symmetric stretch of nitrate (Handayani, 2013). On the other hand, the characteristic peak of $\mathrm{LDH}$ at $601,408 \mathrm{~cm}^{-1}$ which are $\mathrm{Al}-\mathrm{O}$ and $\mathrm{Mg}-\mathrm{O}$ vibration. Figure $1 \mathrm{~B}$ shows the peaks of the functional group of Polyoxometalate $\mathrm{H}_{3}\left[\alpha-\mathrm{PW}_{12} \mathrm{O}_{40}\right] \cdot n \mathrm{H}_{2} \mathrm{O}$. The characteristic of Polyoxometalate is shown at 802, 894, 987 and $1080 \mathrm{~cm}^{-1}$ which are related to the W-Oc-W, W-Ob-W, W=O, and P-O. Figure $1 \mathrm{C}$ in comparison LDH-POM (1:1) shows the presence of a vibrational peak at $3479.5 \mathrm{~cm}^{-1}$ which are related to $\mathrm{O}-\mathrm{H}$ group vibration. The absorption band at $1635.6 \mathrm{~cm}^{-1}$ is indicated buckling of the adsorbed $\mathrm{O}-\mathrm{H}$ group on interlayer and absorbing bands at $1381 \mathrm{~cm}^{-1}$ showing symmetrical nitrate synthesis yield of double layer hydroxide. The three vertices of this vibration are also shown in the FT-IR spectrum of Figure 1D (1:2), 1E (1:3) and 1F (2:1). These three peaks indicate the presence of double layer hydroxide material. The differences presented based on the FT-IR spectrum in Figure 1 are shown by the presence of Polyoxometalate. Figure $1 \mathrm{C}$ show a vibration peak for a polyoxometalate at $663 \mathrm{~cm}^{-1}$ which is a vibration of W-Oc-W. Figure 1D shows the peak vibration of polyoxometalate at $887-810,987$ and $1080 \mathrm{~cm}^{-1}$ which are related to the $\mathrm{W}-\mathrm{Oc}-\mathrm{W}, \mathrm{W}-\mathrm{O}$, and $\mathrm{P}-\mathrm{O}$ vibration. In Figure $1 \mathrm{E}$ at 1018 and $786 \mathrm{~cm}^{-1}$ are related W-Oc-W and P-O vibration. Whereas in Figure $1 \mathrm{~F}$ shows the existence of polyoxometalate at $671 \mathrm{~cm}^{-1}$ is W-Oc-W vibration.

\section{Characterization of $\mathrm{LDH}$, Polyoxometalate $\mathrm{H}_{3}[\alpha-$ $\left.\mathrm{PW}_{12} \mathrm{O}_{40}\right] \cdot \mathrm{nH}_{2} \mathrm{O}$ and Intercalation Result Using X-Ray Difraction}

Polyoxometalate $\mathrm{H}_{3}\left[\alpha-\mathrm{PW}_{12} \mathrm{O}_{40}\right] \cdot n \mathrm{H}_{2} \mathrm{O}$ characterization using XRD. The diffraction is shown in Figure 2.

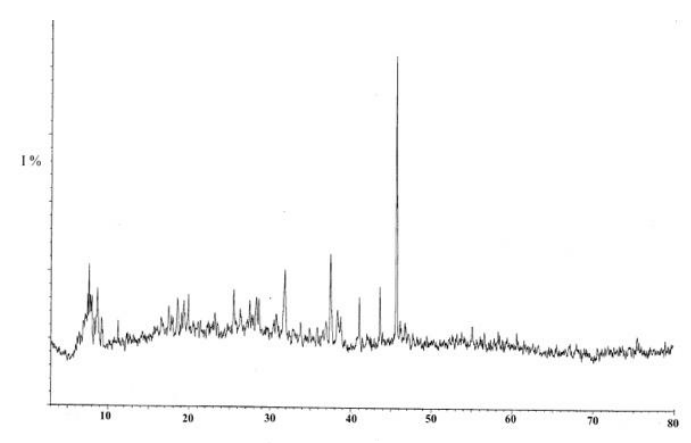

$2 \theta$ (Degree)

Figure 2. X-ray diffraction of polyoxometalate $\mathrm{H}_{3}[\alpha$ $\left.\mathrm{PW}_{12} \mathrm{O}_{40}\right] \cdot n \mathrm{H}_{2} \mathrm{O}$

Figure 2 shows the X-ray diffraction patterns of $\mathrm{H}_{3}[\alpha-$ $\left.\mathrm{PW}_{12} \mathrm{O}_{40}\right] \cdot n \mathrm{H}_{2} \mathrm{O}$ with the principal regions of $2 \theta$ ie $6-10^{\circ}, 15-$ $20^{\circ}, 22-25^{\circ}$ and $35-45^{\circ}$ wherein those diffractions are characteristic for crystalline Polyoxometalate $\mathrm{H}_{3}[\alpha-$ $\left.\mathrm{PW}_{12} \mathrm{O}_{40}\right] \cdot n \mathrm{H}_{2} \mathrm{O}$ (Zhang et al, 2012). The results of the measurement analysis are known to have the largest peaks appear in regions $7^{\circ}$ and $37-45^{\circ}$. The presence of diffraction patterns that appear in the $2 \theta$ region below $10^{\circ}$ denotes the typical peak of the polyoxometalate $\mathrm{MO}_{6}$ where $\mathrm{M}$ is tungsten and has high crystallinity. Polyoxometalate $\mathrm{H}_{3}[\alpha-$ $\left.\mathrm{PW}_{12} \mathrm{O}_{40}\right] \cdot n \mathrm{H}_{2} \mathrm{O}$ are subsequently intercalated into a double layer hydroxide material which aims to increase the distance 
between the double layer hydroxide layers. The double layer hydroxide material and the intercalated double layer hydroxide are presented in Figure 3.

From the Figure3A, Double layer hydroxide diffraction was showing the highest peak at $27^{\circ}-29^{\circ}$ which is demonstrated double layer hydroxide material. Figure $3 \mathrm{~B}$ shows the interfraction pattern of double layer hydroxide material intercalated polyoxometalate with the ratio $(1: 1)$ there is the highest diffraction peak that is in the area at $10,8^{\circ}, 22,4^{\circ}$ and $8,9^{\circ}$. Figure $3 \mathrm{~B}$ shows diffraction peak at $10.8^{\circ}, 22.4^{\circ}$ and $34.1^{\circ}$ are having relatively high crystallinity (Kloprogge et al 1999). According, to Wiyantoko (2015), these three diffraction shows the properties of double-layer hydroxide materials, which have layered structures with intensity are 340, 156 and 101. The regions appearing at $60-63^{\circ}$ indicate the presence of anions in the interlayer of the layered material. Based on this data can be expressed comparison compared to the ratio in $(1: 1),(1: 3)$ and (2: 1).

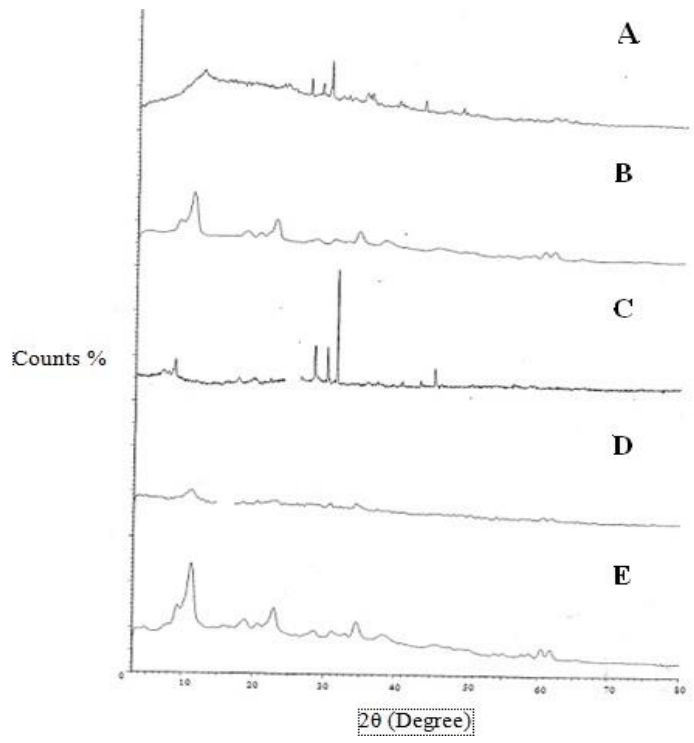

Figure 3. Diffractogram XRD (A) Double layer hydroxide (B) Intercalation of Double Layered Hydroxide with

Polyoxometalate with a rasio of 1:1 (C) 1:2 (D) 1: 3 (E) 2: 1.

Figure 3C shows the different angles of the diffraction form showing the existence of double layer hydroxide material at $2 \theta$ $=10.9^{\circ} .22 .88^{\circ}$ and $34.4^{\circ}$ and indicating the diffraction of the success of the anions, which is presented in a double layer hydroxide material at $60.4^{\circ}$ and $61.7^{\circ}$ with a relatively smaller intensity than the diffraction Fig (1:1) and (2: 1). Figure $3 \mathrm{D}$ $(1: 1)$ is successfully synthesized wherein the polyoxometalate enters the interlayer of the double layer hydroxide material.

Figure $3 \mathrm{E}$ also shows the existence of double layer hydroxide material at $2 \theta=11.12^{\circ}, 22.85^{\circ}$ and $34.5^{\circ}$ which have greater intensity are 518, 192 and 133 than on comparison (1: 1), (1: 2) and (1: 3). The diffraction shows the success of intercalation process of double layer hydroxide material with polyoxometalate at $2 \theta=60,4^{\circ}$ and $61,7^{\circ}$ which has greater intensity than on (1: 1), $(1: 2)$ and $(1: 3)$ are 71 and 72.

\section{Characterization of $\mathrm{LDH}$ and $\mathrm{LDH}$ Intercalated} Polyoxometalate $\mathrm{H}_{3}\left[\alpha-\mathrm{PW}_{12} \mathrm{O}_{40}\right] \cdot \mathrm{nH}_{2} \mathrm{O}$ Using TG-DTA

Double layer hydroxide obtain was then characterized using TG-DTA analysis. The purpose of Thermogravimetric Analyzer (TGA) analysis was used to record changes in sample weight as a function of temperature and Differential Thermal Analyzer (DTA) to detect changes in the heat content. The TG-DTA analysis of the double layer hydroxide has a thermogram pattern as shown in Figure 4.

Figure 4 shows the double layer hydroxide decomposed with the loss of water molecules at $77-102^{\circ} \mathrm{C}$ with weight loss about $23 \%$ (Xie, 2006). From the thermogram could be seen a sharp peak DTA at a temperature of $77-102^{\circ} \mathrm{C}$.

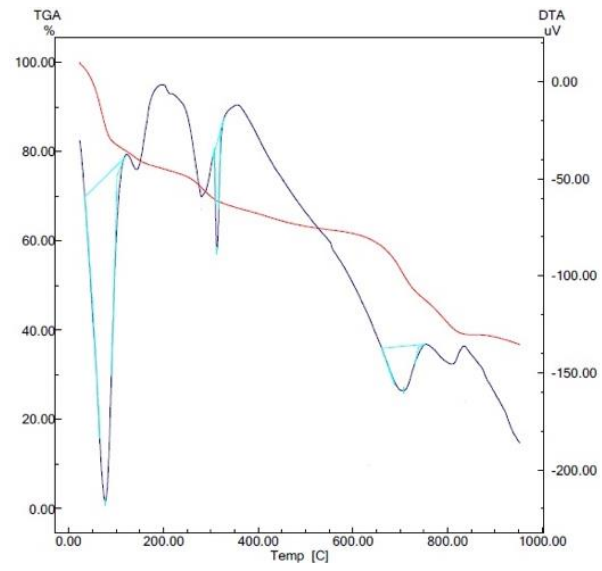

Figure 4. Termogram of Double Layer Hydroxide Material

At $300-320^{\circ} \mathrm{C}$, which is the decomposition of the $\mathrm{OH}$ group of the interlayer material of the double layer hydroxide material with a loss of weight is $15.22 \%$ indicated on the red line ie the weight loss. The endothermic peak at $308{ }^{\circ} \mathrm{C}$ indicates loss of carbonate (Li, et al. 2013). According to $\mathrm{Yu}$ (2009), dehydroxylation process and loss of $\mathrm{Mg} / \mathrm{Al}-\mathrm{CO}_{3}-$ ions at the endothermic peak are seen at temperatures around $220^{\circ} \mathrm{C}$. The endothermic peak at $650-750^{\circ} \mathrm{C}$ indicates a double layer hydroxide material decomposition in the presence of an endothermic peak marked by loss of carbonate ions attached to $\mathrm{Mg}^{2+}$ dan $\mathrm{Al}^{3+}$ with a weight loss about $22.89 \%$ (Lin et al, 2001).

The intercalation of double layer hydroxide with polyoxometalate $\mathrm{H}_{3}\left[\alpha-\mathrm{PW}_{12} \mathrm{O}_{40}\right] \cdot n \mathrm{H}_{2} \mathrm{O}$ by weight ratio (2: 1 ) has a thermogram pattern as in Figure 5.

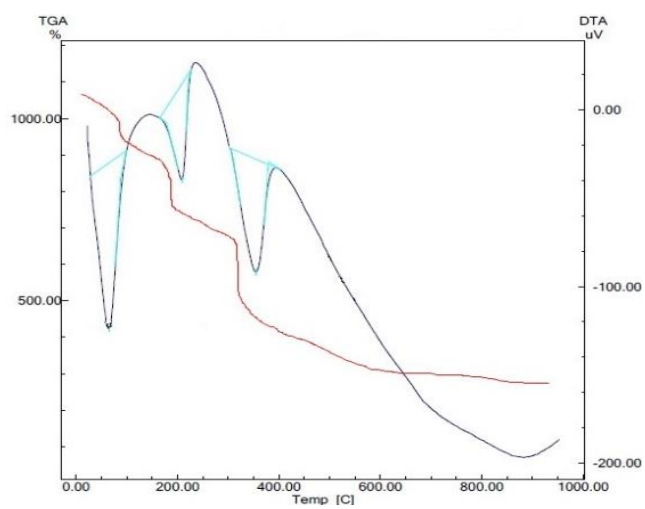

Figure 5. Thermogram Intercalation Result of Double Hydroxy with Polyoxometalate $\mathrm{H}_{3}\left[\alpha-\mathrm{PW}_{12} \mathrm{O}_{40}\right] \cdot n \mathrm{H}_{2} \mathrm{O}$ 
Figure 5 shows the presence of three endothermic peaks. The first endothermic peak at a temperature of $20-90{ }^{\circ} \mathrm{C}$ is due to the loss of water molecules. At the second endothermic peak at temperatures of $170-220{ }^{\circ} \mathrm{C}$ is demonstrated the decomposition marked by the loss of the $\mathrm{OH}$ group present in the interlayer (Zhang et al, 2012).

The third endothermic peak is at a temperature of 300-400 ${ }^{\circ} \mathrm{C}$ which is a decomposition of a polyoxometalate $\mathrm{H}_{3}[\alpha-$ $\left.\mathrm{PW}_{12} \mathrm{O}_{40}\right] \cdot n \mathrm{H}_{2} \mathrm{O}$ with loss of hydrogen bonds between $\mathrm{H}_{3}[\alpha-$ $\left.\mathrm{PW}_{12} \mathrm{O}_{40}\right] \cdot n \mathrm{H}_{2} \mathrm{O}$ with hydrogen ions (Khozhevnikov, 2012).

\section{CONCLUSION}

Intercalation double layer hydroxide with polyoxometalate $\mathrm{H}_{3}\left[\alpha-\mathrm{PW}_{12} \mathrm{O}_{40}\right] \cdot \mathrm{nH}_{2} \mathrm{O}$ in the optimal ratio (2: 1$)$ characterized using FT-IR spectrophotometer has not demonstrated the success of the optimal intercalation process and the characterization using XRD indicates a gallery height of $7.8 \AA$ before The process of intercalation to $7.9 \AA$ after the intercalation process. Further characterization using TG-DTA analysis showed $\mathrm{OH}$ loss in the layer at temperature $170-220^{\circ} \mathrm{C}$ while for decomposition of polyoxometalate $\mathrm{H}_{3}[\alpha-$ $\left.\mathrm{PW}_{12} \mathrm{O}_{40}\right] \cdot \mathrm{nH}_{2} \mathrm{O}$ was at $300-400^{\circ} \mathrm{C}$.

\section{REFERENCES}

Abderrazek, K., Najouna, F.S., and Srasra, E. 2016. Synthesis and Characterization of [ $\mathrm{Zn}-\mathrm{Al}] \mathrm{LDH}$ : Study of The Effect of Calcination on the Photocatalytic Activity. Applied Clay Science.119:229-235.

Beaudot, O., Roy, De., and Besse. 2004. Intercalation of Noble Metal Complexes in LDH Compounds. Journal of Solid State Chemistry. 177(8): 2691-2698.

Franchi, J.G., Mangialardo, R.C., Lazzari, R.T., Vog, J.C., Fernandez, J.L., and Yoshida, R. 1991. Industrial Minerals. Brazil: Ed.Abbim.

Goodarzi, A.R., Fateh, S. N., and Shekary, H. 2016. The impact of Organic Pollutants of The Macro and Micro Structure Responses of Na-Bentonite. Journal Applied Clay Science. 121: 17-28.

Guo, L., Ming, Y., Shan, R and Qin, H. 2014. Adsorptive removal of phosphate by $\mathrm{Mg}-\mathrm{Al}$, and $\mathrm{Zn}-\mathrm{Al}$ layered double hydroxides: Kinetics, isotherms, and mechanisms. Journal of Separation and Purification Technology. 124: 36-42.
Handayani, Sri., Kusumawardani, Cahyono., dan Budiasih, Sri. 2013. Sintesis Senyawa Sinamalaseton melalui Reaksi Hidrotalsit Mg-Al untuk Aplikasi Tabir Surya.Yogyakarta: UNY.

Kloprogge, Theo, J., and Frost, Ray, L. 1999. Fourier Transform Infrared and Raman Spectroscopic Study of The Local Structure of Mg-, Ni-, and Co- Hydrotalcite. Journal of Solid State Chemistry. 146: 506-515.

Kozhevniov, I.V., 2002. Catalysts for Fine Chemical Synthesis Catalysis by Polyoxometalate. UK: University of Liverpool.

Li, Shou., Bai, Z., and Choo, D., 2013. Characterization and Friction Performance of $\mathrm{Zn} / \mathrm{Mg} / \mathrm{Al}-\mathrm{CO} 3$ Double layer hydroxides. Applied Surface Science. 284: 7-12.

Lin, Xu., Chang-wen, Hu., and En-Bu, W. 1997. Advance in Study of a New Class of Pillared Layered Microporous Material Polyoxometalate type Hydrotalcite-Like Catalysis. Journal of Natural Gas Chemistry. 6(2): 155.

Wiyantoko, B., Kurniawati, P., and Fatimah. 2015. Synthesis and Characterization of Hydrotalcite at Different $\mathrm{Mg} / \mathrm{Al}$ molar Ratio. Procedia Chemistry. 17: 21-26.

Xie, W., Reng, hong., Chem, L., 2006. Calcined Mg/Al hydrotalcite as Solid based Catalysis for Methanolysis of Soybean Oil. Journal of Molecular Catalysis. 246: 24-32.

Yang, S., Huang, Y., and Li Yu., 2011. Catalytic Application of $\mathrm{H} 4 \mathrm{SiW} 12 \mathrm{O} 40 / \mathrm{SiO} 2$ in Synthesis of Acetals and Ketals. Advanced Materials Research, 284-286: 2374-2379.

Yu, S., Shan, R., Yang, M and Du, B. 2015. Highly efficient removal of three red dyes by adsorption onto $\mathrm{Mg}$-Al-layered double hydroxide. Journal of Industrial and Engineering Chemistry. 21: 561-568.

Zhang, Y., Su, J., Pang, Q., and Qu, W. 2012. Polyoxometalate intercalated $\mathrm{MgAl}$ Double layer hydroxide And its Photocatalytic Performance. Journal of Material Science and Engineering. 2(1):59-63.

Zhang, S., Chen, L., Liu, Hong., and Yang, Y. 2012. The design of H3PW12O40/TiO2 and Ag/H3PW12O40/TiO2 filmcoated optical fiber photoreactor for the degradation of aqueous rhodamine $\mathrm{B}$ and 4-nitrophenol under simulated sunlight irradiation. Journal of Chemical Engineering. 200: 300-309. 